\title{
Traditional Healing Methods: Focus on the Medicinal Plants Against Coronavirus (COVID-19) Infection
}

\author{
Yusuf-Babatunde Moruf Ademola ${ }^{1, \text { * }}$, Quadri Jelili Akorede ${ }^{2}$, Solaja Olatunde Odutola ${ }^{3}$, \\ Kuku Mukaila Akorede ${ }^{4}$ \\ ${ }^{1}$ Department of Pharmacy Techniques, Ogun State College of Health Technology, Ilese-Ijebu, Nigeria \\ ${ }^{2}$ Department of Nutrition and Dietetics, Ogun State College of Health Technology, Ilese-Ijebu, Nigeria \\ ${ }^{3}$ Department of Environmental Health Science, Ogun State College of Health Technology, Ilese-Ijebu, Nigeria \\ ${ }^{4}$ Department of Health Education, Ogun State College of Health Technology, Ilese-Ijebu, Nigeria
}

Email address:

ogbonronka@gmail.com (Yusuf-Babatunde M. A.)

${ }^{*}$ Corresponding author

\section{To cite this article:}

Yusuf-Babatunde Moruf Ademola, Quadri Jelili Akorede, Solaja Olatunde Odutola, Kuku Mukaila Akorede. Traditional Healing Methods: Focus on the Medicinal Plants Against Coronavirus (COVID-19) Infection. Journal of Diseases and Medicinal Plants.

Vol. 7, No. 1, 2021, pp. 6-13. doi: 10.11648/j.jdmp.20210701.12

Received: December 23, 2020; Accepted: January 8, 2021; Published: February 9, 2021

\begin{abstract}
Background: In African health care system, medicinal plants are major components and most assorted of all therapeutic systems. In major parts of rural Africa, traditional healers prescribing medicinal plants are the most easily accessible and affordable health resource available to the local community and at times the only therapy that subsists. Coronavirus diseases (COVID-19) is an acute virus (SARs-coV-2) which has caused a global pandemic. This paper aims to emphasize the importance of herbal medicine as a possible alternative and effective immune system booster against coronavirus disease in Ogun state, Nigeria. Materials and Methods: Ethnobotanical survey was carried out using 80 randomly selected respondents among the villagers, herbalists, herb sellers, traditional medical practitioners, students, community leaders, by oral interviews and semi-structured questionnaire. The data were analyzed using frequency counts and percentages. Results: A total of 81 plant species from 35 families which were mostly represented by Euphorbiaceae, Moraceae, Apocynaceae and Rubiaceae, and 61 botanicals were used singly while 21 other botanicals were combination of two or more plants in a single herbal preparations reported in the study area are used for management and alternative therapy against ailments such as fever, cough, body pain, flu, cold and shortness of breath that are associated to symptoms of COVID-19. Conclusion: Herbal medicines provide an alternative therapy for boosting immunity system to help fight coronavirus. Traditional healers are still very relevant to African healthcare system.
\end{abstract}

Keywords: Traditional Healing, Medicinal Plants, Coronavirus, Infection, Ethnobotanical Survey

\section{Introduction}

In Africa and other parts of the World, herbal medicines have been in forefront of primary health care system. Household preparations in the forms of infusion and decoction were used to treat common ailments. Herbs are taken on diet to diagnose, prevent or treat diseases locally. Based on the Ethno-botanical studies, several active compounds have been discovered from plants and are used directly as potential in the production of synthetic drugs [1]. Due to the use and importance of African herbal plants, many developing countries intensified efforts on documentation of ethno-botanical data of herbal plants, as most traditional herbalists keep inadequate records and their information is passed on, mainly through verbal, from generation to generation [2]. In Nigeria, indigenous population have been using herbal medicines for a long time for the treatment of many diseases [3]. The novel coronavirus known as SARS-COV-2 (Severe Acute Respiratory Syndrome Coronavirus 2) outbreak was 
recorded for the first time in Wuhan City and Hubei Province, China on December 8, 2019 [4]. Generally, the statistics of symptoms of COVID-19 were fever in $83 \%$ to $98 \%$ of patients, dry cough in $76 \%$ to $82 \%$, and fatigue in $11 \%$ to $44 \%$. Other reported symptoms are sore throat, headache, diarrhoea and abdominal pain [4]. The global outbreak of COVID-19 presents different challenges to develop and developing countries. Most developing countries have weak health system coupled with inadequate epidemic response capacity. So far, Nigeria has successfully dealt with individual cases, the country reported 54,905 recorded cases, 1,054 deaths and 42,922 discharged cases from coronavirus infection as of September $5^{\text {th }}, 2020$ [5]. In Nigeria, herbs are used to treat and manage infections and diseases as part of their tradition and custom. The indigenous knowledge could be inherited or learnt in traditional religion. The dependency on botanicals has been attributed to the availability of a diversity of medicinal plants in the lowland rain forest vegetation, presumed efficacy of herbal remedies in regimens with little or low side effect and affordability [4]. COVID-19 is a viral infection, therefore, use of antiviral herbal medicines might be useful in its prevention and management. Considering COVID-19 infection symptoms fever, body pain, cough, flu, cold and shortness of breath, plants with antimalarial effect, cough remedy, analgesic properties and a plausible therapeutic effect in respiratory tract infections could be useful to prevent infection due to COVID-19 [6]. The objective of this paper is to document ethnomedicinal plants in Ogun state that can be used to boost immunity thereby prevent the coronavirus infection.

\section{Materials and Methods}

\subsection{Study Area}

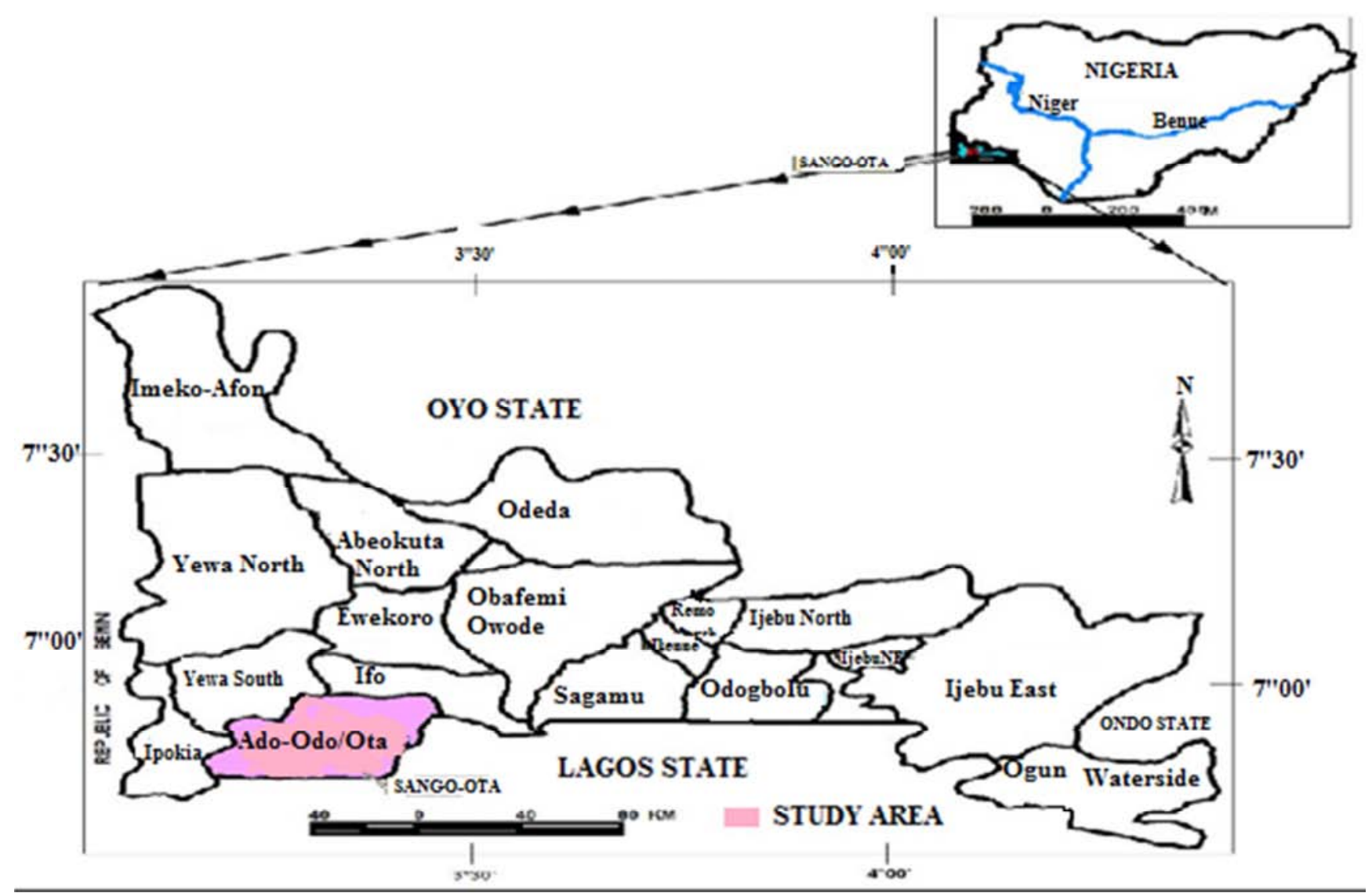

Figure 1. Areas in Ogun State, Nigeria Surveyed for the Use of Plant/Herbal Preparations to boost immunity against coronavirus.

The study area covers Ota, Sango-Ota, Ado-Odo, Agbara, Iju-Ota, Itele, Igbesa, Owode-Ijako and Koko-Ebiye in AdoOdo/Ota Local Government Area in Ogun State, Nigeria. The ethnic composition is Yoruba with sub-groups of Awori, Yewa, Egba, Ijebu and Remo. Ado-Odo/Ota Local Government Area covers approximately $16,762 \mathrm{~km}^{2}$ area with a total population of $3,751,140$ residents from 2006 census [7]. It borders Lagos State to the south, Ondo State to the east, Osun State to the north and Republic of Benin to the west (Figure 1). It was created in May 19, 1989, when Ota was merged with the defunct Ifo/Ota Local Government with Ado-Odo/Igbesa Areas of Yewa South Local Government and the second most populated Local Government in Ogun State. It's headquarter is Ota at $6^{\circ} 41^{\prime} 00^{\prime}$ 'N $3^{\circ} 41^{\prime} 00^{\prime \prime} \mathrm{E}$ to the 
north of the Area (Figure 1). It's an agrarian in nature, produces cash and food crops such as cocoa, kola, coffee, palm oil, nut, cassava, maize, timber and vegetables [8].

\subsection{Collection of Information}

Ethno-medicinal information was gathered from herbalists, herb sellers, villagers and other residents using semistructured questionnaire and oral interviews as described by Jovel et al, (1996) [7], Yusuf-Babatunde and Solaja (2019) [8]. For the purpose of this study, Eighty (80) questionnaires were administered to respondents and they provided local names of the herbal plants being used to boost immunity against coronavirus infection. The questionnaire was divided into three sections: section one furnished demography data, section two was about awareness, prevention and treatment of coronavirus infection and section three dealt with plants/recipes used in the prevention and management of coronavirus infection. Botanical names of the plants were authenticated by comparison with appropriate voucher specimen at herbarium in Forestry Research Institute of Nigeria (FHI) Ibadan; (where herbarium specimens are kept) and by reference to standard botanical classifications and nomenclature $[10,11]$. Identification was also confirmed at Herbarium of Faculty of Pharmacy, Olabisi Onabanjo University, Sagamu [11]. The socio-economic characteristics of the respondents revealed 46 females and 34 males. Seventy-three percent of the respondent had primary to secondary formal education. The respondents were between 30 to 70 years old. Eighty-seven percent of the respondents were trade specialists (i.e., herbalists/herb sellers) and the rest did not have any specialized training in traditional medicine but claimed experience to ancestral traditions (Table 1).

\section{Results and Discussion}

The results of the survey of botanicals to boost immunity and prevent Coronavirus disease are presented and the plants are listed in Tables 1 and 2. Each plant is identified by a voucher specimen number, and pharmacognostic elements such as botanical name, common and local name, parts used, and method of preparation are provided.

Table 1. Demographic Characteristics of Respondents.

\begin{tabular}{llll}
\hline Variables & Respondents & N & (\%) \\
\hline Gender & Male & 34 & 42.5 \\
Total & Female & 46 & 57.5 \\
& & 80 & 100 \\
Age & $30-40$ & 10 & 12.5 \\
& $41-50$ & 18 & 22.5 \\
Total & $51-60$ & 31 & 38.75 \\
& $61-70$ & 21 & 26.25 \\
Educational status & & 80 & 100 \\
Total & Primary & 68 & 85 \\
& Secondary & 12 & 15 \\
Occupation & Tertiary & --- & 100 \\
& & 80 & 13.75 \\
Total & Farmer & 11 & 45 \\
& Herbalist & 36 & 41.25 \\
Religion & Herb seller & 33 & 100 \\
Total & & 80 & 40 \\
\hline
\end{tabular}

Table 2. List of Botanicals used to boost immunity against fever associated diseases in Ado-Odo/Ota Local Government Area of Ogun State in Ogun State, Nigeria.

\begin{tabular}{|c|c|c|c|c|c|c|}
\hline $\mathbf{S} / \mathbf{N}$ & Botanical Name & Local Name & Common Name & Families & $\begin{array}{l}\text { Morph. Part } \\
\text { used }\end{array}$ & Method of preparation \\
\hline 1. & Morinda lucida Benth & Oruwo & Brimstone tree & Rubiaceae & Leaves, Root & Infusion \\
\hline 2. & Cymbopogon citratus & Ewe lemon & Lemon grass & Poaceae & Leaves & Decoction \\
\hline 3. & Azadirachta indica, Juss & Dongoyaro & Neem Tree & Meliaceae & Leaves, Bark & Decoction \\
\hline 4. & Citrus aurantifolia chrism & Osan wewe & Lime orange & Rutaceae & Leaves & Decoction \\
\hline 5. & Citrus aurantium bergamia & Osan jaganyin & bergamot orange & Rutaceae & Fruit juice & Infusion \\
\hline 6. & Terminalia catappa & Igi-furuntu & Umbrella tree & Combretaceae & Leaves & Decoction \\
\hline 7. & Croton lobatus $L$. & Arorososo & Rush foil & Euphorbiaceae & Fruit & Decoction \\
\hline 8. & Lawsonia inermis Linn & Laa-li & Henna Tree & Lythraceae & Leaves & Decoction \\
\hline 9. & Khaya senegalensis & Oganwo & African mahogany & Meliaceae & Bark & Infusion \\
\hline 10. & Jatropha curcas $L$. & Lapalapa & $\begin{array}{l}\text { Physical nut or } \\
\text { purging nut }\end{array}$ & Euphorbiaceae & Leaves & Decoction \\
\hline 11. & Newbouldia laevis & Akoko & Boundary tree & Bigoniaceae & Root & Decoction \\
\hline 12. & Momordica charantia Linn & Ejirin wewe & Bitter mellon & Cucurbtaceae & Leaves, Bark & Decoction \\
\hline 13. & Mangifera indica & Mangoro & Mango tree & Anacardiaceae & Leaves & Decoction \\
\hline
\end{tabular}




\begin{tabular}{|c|c|c|c|c|c|c|}
\hline $\mathbf{S} / \mathbf{N}$ & Botanical Name & Local Name & Common Name & Families & $\begin{array}{l}\text { Morph. Part } \\
\text { used }\end{array}$ & Method of preparation \\
\hline 14. & Enantia chlorantha Oliver & Baka & African yellow wood & Annonaceae & $\begin{array}{l}\text { Leaves, Stem bark } \\
\text { and Roots }\end{array}$ & Decoction \\
\hline 15. & Psidium guajava, & Guafa & Guava Tree & Myristaceae & Leaves & Decoction \\
\hline 16. & Chromolaena odorata & Akintola-ta-ku & Baby bush & Compositae & Leaves & Decoction \\
\hline 17. & Macaranga barteri, & Ohaha & Macaranga & Euphorbiaceae & Leaves, Stem bark & Decoction \\
\hline 18. & Cajanus cajan L. & Otiili & Pigeon pea & Fabaceae & Leaves & Decoction \\
\hline 19. & Ficus capensis & Opoto & Bush fig & Moraceae & Leaves & Decoction \\
\hline 20. & $\begin{array}{l}\text { Alchornea cordifolia } \\
\text { (Schum and Thern) mil. }\end{array}$ & Ewe-epa & Christmas bush & Euphobiaceae & Leaves & Decoction \\
\hline 21. & Massularia acuminata & Pako/Orin ijebu & Chewing stick tree & Rubiaceae & $\begin{array}{l}\text { Stem, Root \& } \\
\text { Leaves }\end{array}$ & $\begin{array}{l}\text { Chewing stick, } \\
\text { Decoction }\end{array}$ \\
\hline 22. & Ageratum conyzoides & Imi-eshu & Goatweed/Chickweed & Compositeae & Leaves \& Root & Infusion, Decoction \\
\hline 23. & Zingiber officinale Roscoe & Atale & Ginger & Zingiberaceae & Rhizome & Maceration \\
\hline 24. & Ocimum gratissimum & Efirin & African Basil & Lamicaceae & Leaves & Infusion \\
\hline 25. & Canna indica $L$. & & Arrow root & Cannaceae & Leaves & Decoction \\
\hline 26. & Vernonia amygdalina & Ewuro & Bitter leaf & Asteraceae & Leaves & Infusion \\
\hline 27. & Carica papaya $L$. & Ibepe & Pawpaw & Caricaceae & Fruit & Decoction \\
\hline 28. & Ficus asperifolia L. & Eepin & Sand paper & Moraceae & Root, Leaves & Decoction \\
\hline 29. & Alstonia boonei & Awun & Stool wood & Apocynaceae & Root & Infusion \\
\hline 30. & Capsicum annum & Ata wewe & Red pepper & Solanaceae & Fruit & Ground fruit \\
\hline 31. & Sarcocephalus latifolius & Egbesi & African peach & Rubiaceae & $\begin{array}{l}\text { Fruit, Leaves, } \\
\text { Root }\end{array}$ & Infusion \\
\hline
\end{tabular}

Table 3. List of Botanicals used to boost immunity against Cough associated with respiratory diseases in Ado-Odo/Ota Local Government Area of Ogun State, Nigeria.

\begin{tabular}{|c|c|c|c|c|c|c|}
\hline $\mathbf{S} / \mathbf{N}$ & Botanical Name & Local Name & Common Name & Families & Morph. Part used & $\begin{array}{l}\text { Method of } \\
\text { preparation }\end{array}$ \\
\hline 1. & Abrus precatorius $\mathrm{L}$. & Ojuologbo & Rosary pea & Fabaceae & Leaves & Maceration \\
\hline 2. & Aframomum melegueta $\mathrm{K}$. Schum. & Ataare & Alligator pepper & Zingiberaceae & Dry seed & Infusion \\
\hline 3. & Cissampelos owariensis P. Beauv. & Jokojee/Jenjokoo & Damargaji & Menispermaceae & Leaves & Decoction \\
\hline 4. & Allium ascalonicum $\mathrm{L}$. & Alubosa elewe & Onion & Amaryllidaceae & Leaves & Decoction \\
\hline 5. & Allium sativum $\mathrm{L}$. & Ayu & Garlic & Amaryllidaceae & Bulb & Decoction \\
\hline 6. & Alstonia boonei De Wild. & Awun/doctor igbo & Stool wood & Apocynaceae & Root & Infusion \\
\hline 7. & Anacardium occidentale $\mathrm{L}$. & Kasu & Cashew & Anacardiaceae & Leaves & Decoction \\
\hline 8. & Cocos nucifera $\mathrm{L}$. & Agbon & Coconut & Aracaceae & Fruit & Fruit juice \\
\hline 9. & Garcinia kola Heckel & Orogbo & Bitter cola & Clusiaceae & Fruit & Decoction \\
\hline 10. & Asparagus africanus Lam. & Aluki & Bush asparagus & Asparagaceae & $\begin{array}{l}\text { Leaves, Shoots, } \\
\text { underground stem, } \\
\text { i.e. Whole plant }\end{array}$ & Decoction \\
\hline 11. & $\begin{array}{l}\text { Ocimum americanum L. (Ocimum } \\
\text { canum) }\end{array}$ & Efinrin wewe & Hairy Basil & Lamiaceae & Leaves & Infusion \\
\hline 12. & $\begin{array}{l}\text { Sarcocephalus latifolius (Sm.) E. A. } \\
\text { Bruce }\end{array}$ & Egbesi & African peach & Rubiaceae & Leaves & Decoction \\
\hline 13. & Zea mays L. & Agbado & Corn & Poaceae & Seed & Decoction \\
\hline 14. & Kigelia africana (Lam.) Benth. & Pandoro & Suasage tree & Bignoniaceae & Bark & Decoction \\
\hline 15. & Ficus exasperata Vahl & Eepin & Sand paper & Moraceae & Root & Decoction \\
\hline 16. & Crinum jagus (J. Thomps.) Dandy & Ogede Odo & Banana & Amaryllidaceae & Fruit & Fruit juice+honey \\
\hline 17. & Calotropis procera (Aiton) Dryand & Bomu-Bomu & Apple of Sodom & Apocynaceae & Leaves & Decoction \\
\hline
\end{tabular}

Table 4. Respondents knowledge on the synergistic effect on the combined use of plants to treat body pain, fatigue and loss of appetite in Ado-Odo/Ota Local Government Area of Ogun State, Nigeria.

\begin{tabular}{|c|c|c|c|}
\hline $\mathbf{S} / \mathbf{N}$ & Botanical Names & Local Name & Families \\
\hline 1 & Anarcadium occidentale; Mangifera indica and Spondia mombin. & Kasu, Mangoro, Iyeye. & Anarcardiaceae \\
\hline 2 & Acanthus montanus & Alligator plant /Mountain thistle & Acanthaceae \\
\hline 3 & Alstonia boonei, Rauvolfia vomitora & Awun, Osan-wewe & Apocynaceae \\
\hline 4 & Anchomanes difformis and Culcasia lancifolia & Langbodo, Maraka & Aracaceae \\
\hline 5 & $\begin{array}{l}\text { Tithonia diversifolia, Chromolena odorata, Vernonia amygdalina, Ageratum } \\
\text { conyzoides }\end{array}$ & $\begin{array}{l}\text { Mexican sunflower, Akintola, Ewuro, Imi- } \\
\text { eshu. }\end{array}$ & Asteraceae \\
\hline 6 & Newboulda laevis & Akoko & Bignonaceae \\
\hline 8 & Byrsocarpus coccineus & Amuje wewe & Cannaraceae \\
\hline 9 & Luffa cylindrical, Momordica charantia & Loofa, Tagiri & Cucurbitaceae \\
\hline 10 & Diospyros monbuttensis & Kalwa & Ebenaceae \\
\hline 11 & Alchornea cordifolia, Phyllianthus muellerianus, Euphorbia heterophylla, & Ewe-epa, Egun eja, Egele, Opoto & Euphorbiaceae \\
\hline
\end{tabular}




\begin{tabular}{lll}
\hline S/N & Botanical Names & Local Name \\
\hline & Alchornea laxiflora & Families \\
12 & Theobroma cacao & Koko \\
13 & Myrianthus arboreus P. Beauv., Ficus exasperate & Ujuju, Eepin. \\
14 & Moringa oleifera & Moringa \\
15 & Psidium guajava, Pycnanthus angolensis & Guafa, African Nutmeg \\
16 & Parquetina nigrescens & Ewe Ogbo \\
17 & Sarchocephalus latifolus & Egbes \\
18 & Blighia sapida & Mkee \\
19 & Pneumatopteris afra & Iyan origi/ Iyan-orere \\
20 & Glyphaea brevis (Spreng) Monachino & Mbarambaram \\
21 & Vitex doniana & Black Plum \\
\hline
\end{tabular}

Table 4. Continued.

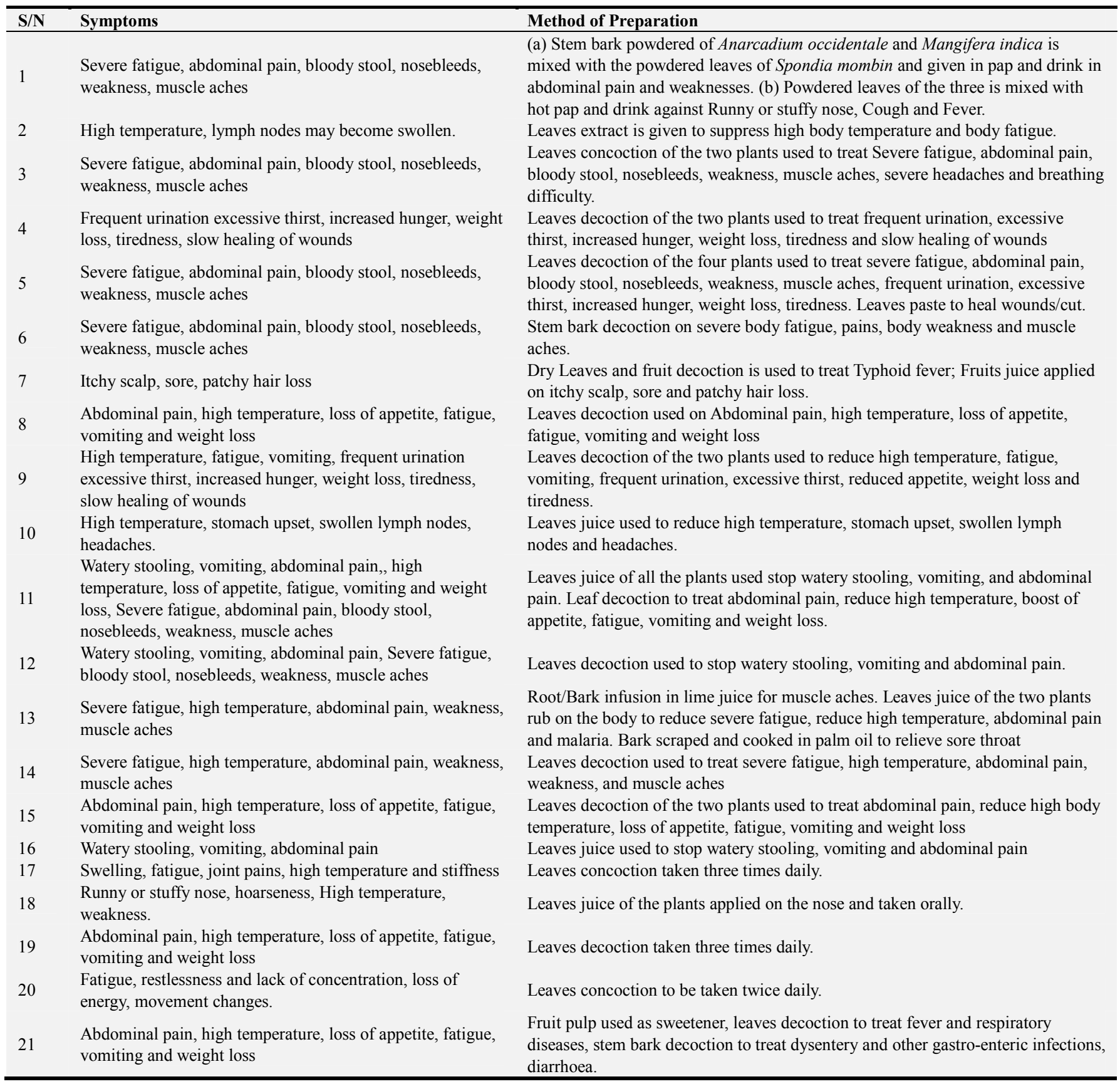




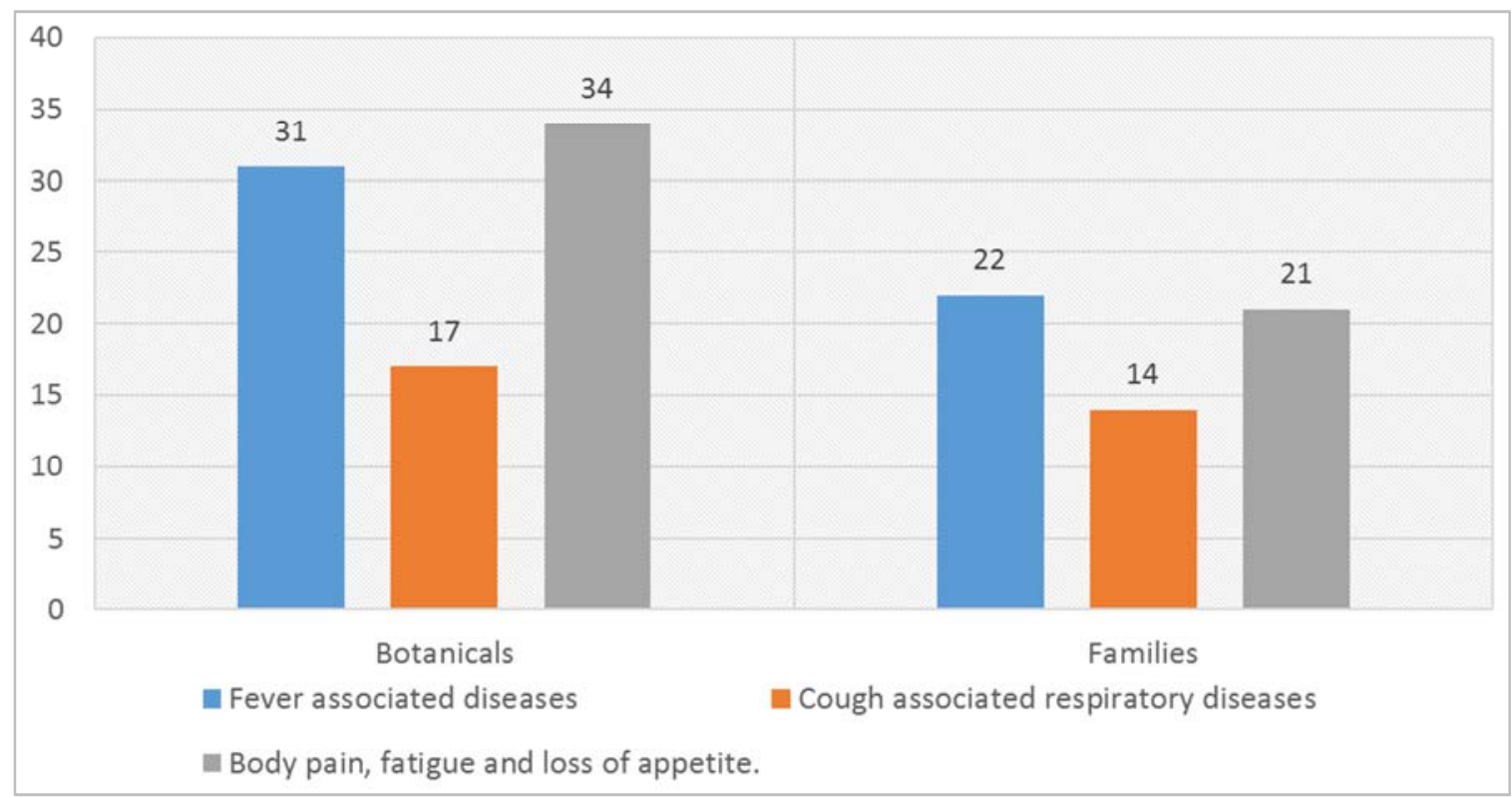

Figure 2. Botanicals and Families of Medicinal Plants against symptoms associated with corronavirus.

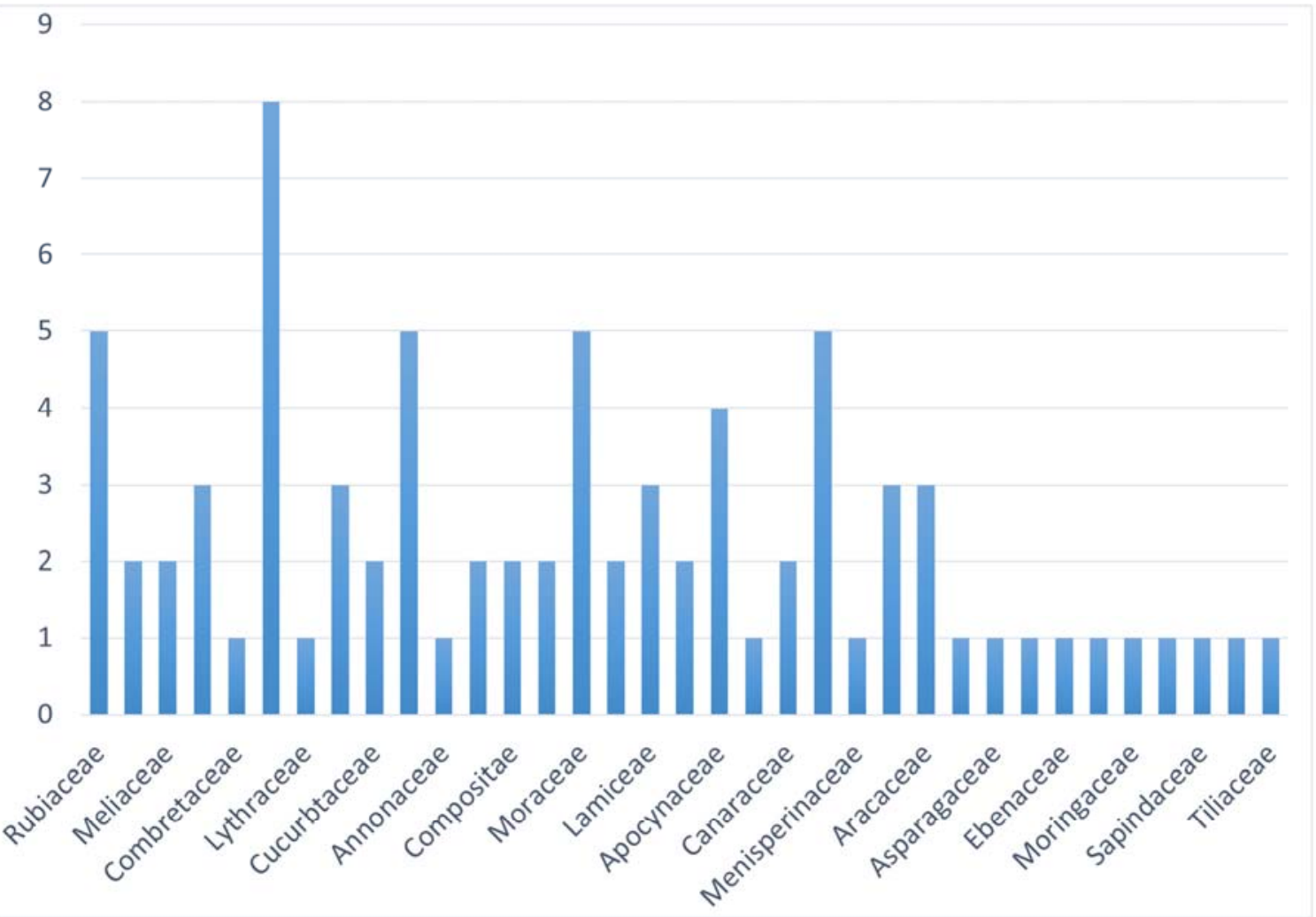

Figure 3. Botanicals and Families of Medicinal Plants to boost immunity against Corronavirus.

In this study area a total number of 31 botanicals belonging to 22 families were frequently used for the treatment of fever associated diseases (Table 2). The different families, largely represented by Euphorbiaceae $(12.9 \%)$,

Rubiaceae

$(9.68 \%)$ Maliaceae $=$ Rutaceae $=$ Compositae $=$ Moraceae $\quad(6.45 \%)$. Leaves had the highest frequency of use $(70.10 \%)$ followed by root $(25.81 \%)$. Decoction is the most preferred method of preparation of the botanicals $(67 \%)$, this is in agreement with the previous ethnomedicinal survey of (Adeyemi et al, (2010) [12]. Most anti-fever herbal recipes were administered orally, and this is in agreement with previous survey results $[13,14]$. However, the majority of the respondents $(65 \%-72 \%)$ preferred herbal preparations to modern drugs for the treatment and prevention of fevers. Most of these herbal antifever recipes have been scientifically justified [15, 16]. According to the study of Igoli et al (2005) [17], some of these recipes were for combination therapy of more than one 
kind of fever, anti-typhoid and anti-malarial herbal recipes were also reported in the survey conducted in the northern part of Nigeria.

To manage cough associated respiratory diseases, 17 locally used herbal plant species from 14 families were documented from the study area (Table 3). Cough remains common symptoms that made people to visit health center/hospital in developed countries [18]. The studies on cough epidemiology are currently scanty in sub-Saharan Africa [19], but it's one of the conditions that are treated with African herbal plants [20-22], an example is a study of about 930 households sampled in Akwa Ibom State, Nigeria, cough ranked $5^{\text {th }}$ among the 10 diseases treated with herbal plants [23]. In South Africa, cough is $2^{\text {nd }}$ to tuberculosis in which herbal plants are used to mitigate by herbalists [24]. In other continents beyond Africa, herbal medicines are used for treating cough, such as India [25], Spain [26], Greece [27], and Yemen [28]. There is continuous and widespread use of herbal plants for mitigating cough as a condition and as part of associated symptoms in many diseases affecting the respiratory system.

Botanical pain relievers: Acanthus montanus (Alligator pepper) leaves, Alstonia boonei (Stool wood) [29], Rauvolfia vomitora (Lime orange) leaves, Newboulda laevis (Boundary tree) Stem bark, Byrsocarpus coccineus (Huntsman's pepper) leaves, Sarchocephalus latifolus (African peach) leaves, Diospyros monbuttensis (Yoruba Ebony) leaves, Theobroma cacao (Cocoa) leaves are used as singly or in combination to relieve abdominal pains, muscle aches, headaches and general body pains. The herbal medicines are prepared as leaf juice, concoction, decoction for treatment purposes.

Herbs for respiratory tract infections: Myrianthus arboreus (Monkey fruit), Ficus exasperate (Sand paper), Spondias mombin (Yellow mombin), Garcinia kola (Bitter cola), Calotropis procera (apple of Sodom), Nymphaea lotus (White Lotus) and Abrus precatorius (Rosary pea) are used for the management and treatment of respiratory tract infections [30]. An example is an infusion of bitter kola and garlic in clean water is used for the management of respiratory tract infections, and this conforms to previous survey results of Gbadamosi, (2019) [31].

Herbal immune boosters: Anarcadium occidentale (Cashew tree) and Mangifera indica (Mango tree) stem bark [32], Spondia mombin (Yellow mombin) leaves, Tithonia diversifolia (Mexican sunflower) leaves, Chromolena odorata (Baby bush) leaves, Vernonia amygdalina (Bitter leaf) leaves, Ageratum conyzoides (Goatweed) leaves, Psidium guajava,(Guava) leaves, Pycnanthus angolensis (African Nutmeg) leaves are immune boosting herbs that can be prepared in powdered form or as a decoction for oral administration. Research has confirmed that eating a small amount of ginger (Zingiber officinale) daily for 11 days or more can reduce muscle pain and inflammation, ginger also aids digestion, [3]. Other useful spices are onions (Allium species), black pepper (Piper guineense), guinea pepper, clove (Syzygium aromaticum) and green onions (Allium ascalonicum), [4].

\section{Conclusion}

This study documents the herbal plants used by indigenous population of Ado-Odo/Ota Local Government Area of Ogun State, Nigeria, to boost immunity against coronavirus (COVID-19) infection.

Herbal medicines provide an alternative therapy for the treatment and management of coronavirus and many diseases in the significant number of people, especially in the rural areas, therefore Nigerian Government should make policies on the preservation of indigenous knowledge, documentation of indigenous recipes, prevention of cultural loss and conservation of important plant species for research and medicine. Scientists should collaborate with indigenous people to promote drug discovery via production of herbal remedies, drug precursors, drug prototypes, and active compounds through research.

\section{Conflict of Interest}

Authors declare no conflict of interest.

\section{References}

[1] Olanipekun and Ajayi Babajide, (2016). Investigation on the Importance of Medicinal Plants Used in Treating Ailments in Ekiti-State, Southwest Zone, Nigeria, Journal of Natural Sciences Research, 6 (13): 68-84.

[2] Hatil H. E., Kamali L (2009). Medicinal Plants in East and Central Africa: Challenges and Constraints Ethnobotanical Leaflets. 13: 364-369.

[3] Sadiq, I. Z., Abubakar, F. S., Ibrahim, B., Usman, M. A. and Kudan, Z. N. (2019). Medicinal plants for management and alternative therapy of common ailments in Dutsin-Ma (Katsina State) in Nigeria, Herba Polonica, 65 (4): 45-55.

[4] Gbadamosi, I. T. (2020). Stay safe: helpful herbal remedies in COVID-19 infection, African Journal of Biomedical Research, 23: 131-133.

[5] NCDC (2020). Nigeria Center for Disease Control Data, Nigeria Television Authority News of 2020-09-06.

[6] Aayushi, K., Soumen, B., Nagaraj, P. S., Ashok, K. M. and Tejraj, M. A. (2020) The COVID-19 paradox: Impact on India and developed nations, Sensor International, 1: 100026.

[7] Ogun State Data (2020). https://en.wikipedia.org/wiki/Ogun State. Retreived 2020-09-08.

[8] Ado-Odo/Ota (2020). https://en.wikipedia.org/wiki/AdoOdo/Ota. Retreived 2020-09-08.

[9] Jovel E. M, Cabanillas J, Towers GHN (1996). An ethnobotanical study of the traditional medicine of the Mestize people of Suni Mirano, Loreto, Peru. Journal of Ethnopharmacology, 53: 149-156.

[10] Yusuf-Babatunde, M. A. and Solaja, O. O. (2019). Ethnomedicinal survey of Medicinal Plants used in the Treatment of Diabetes Mellitus in Ogun State, Fuoye journal of Pure and Applied Sciences (FJPAS), 4 (1): 123-132. 
[11] Abo, K. A., Fredi-Jaiyesimi, A. and Jaiyesimi, E. A. (2008). Ethnomedicinal plants used in the management of Diabetes mellitus in South Western Nigeria, Journal of Ethnopharmacology, 115: 67-71.

[12] Adeyemi, A. A., Gbolade, A. A., Moody, J. O., Ogbole, O. O. and Fasanya, M. T. (2010). Traditional Anti-fever Phytotherapies in Sagamu and Remo North Districts in Ogun State, Nigeria. Journal of Herbs, Spices and Medicinal Plants, 16: 203-218.

[13] Tor-Anyiin, T. A., R. Sha'ato, and H. O. A. Oluma. 2003. Ethnobotanical survey of antimalarial medicinal plants amongst the Tiv people of Nigeria. Journal of Herbs, Spices and Medicinal Plants 10: 61-74.

[14] Odugbemi, T. O., O. R. Akinsulire, I. E. Aibinu, and P. O. Fabeku. 2007. Medicinal plants useful for malaria therapy in Okeigbo, Ondo State, Southwest Nigeria. Afr. J. Trad. CAM 4: 191-198.

[15] Moody, J. O., Hylands, P. J. and Bray, D. H. (1994). Droplet counter-current separation of bioactive constituents of Morinda lucida Benth root bark. Pharm. Pharmacol. Lett. 4: 29-31.

[16] Moody, J. O., Hylands, P. O. and Bray, D. H. 1995. In vitro evaluation of Enantia chlorantha constituents and derivatives for antiplasmodial and anticandidal activity. Pharm. Pharmacol. Lett. 2: 80-82.

[17] Igoli, J. O., Ogaji, D. H., Tor-Anyiin, T. A and Igoli, N. P. (2005). Traditional medicine practice amongst the Igede people of Nigeria. Part II. Afr. J. Trad. CAM, 2: 134-152.

[18] Morice, A. H. (2002). Epidemiology of cough. Pulm. Pharmacol. Ther, 15: 253-259.

[19] Desalu, O. O.; Salami, A. K. and Fawibe, A. E. (2011). Prevalence of cough among adults in an urban community in Nigeria. West Afr. J. Med., 30: 337-341.

[20] Disengomoka, I. and Delaveau, P. (1983). Medicinal plants used for child's respiratory diseases in Zaire. Part I. Journal of Ethnopharmacology, 8: 257-263.

[21] Anywar, G.; Kakudidi, E.; Byamukama, R.; Mukonzo, J.; Schubert, A.; Oryem-Origa, H. (2020). Indigenous traditional knowledge of medicinal plants used by herbalists in treating opportunistic infections among people living with HIV/AIDS in Uganda. Journal of Ethnopharmacology, 246: 112205.
[22] Kayode, J. (2006). Conservation of indigenous medicinal botanicals in Ekiti State, Nigeria. J. Zhejiang Univ. Sci. B, 7: 713-718.

[23] Ajibesin, K. K.; Ekpo, B. A.; Bala, D. N.; Essien, E. E. and Adesanya, S. A. (2008). Ethnobotanica survey of Akwa Ibom State of Nigeria. Journal of Ethnopharmacology., 115: 387408 .

[24] Semenya, S. S. and Maroyi, A. (2018). Data on medicinal plants used to treat respiratory infections and related symptoms in South Africa. Data Brief, 21: 419-423.

[25] Ballabh, B. and Chaurasia, O. P. (2007). Traditional medicinal plants of cold desert Ladakh-Used in treatment of cold, cough and fever. Journal of Ethnopharmacology, 112: 341-349.

[26] Cavero, R. Y. and Calvo, M. I. (2014). Medicinal plants used for respiratory affections in Navarra and their pharmacological validation. Journal of Ethnopharmacology, 158: 216-220.

[27] Petrakou, K.; Iatrou, G. and Lamari, F. N. (2020). Ethnopharmacological survey of medicinal plants traded in herbal markets in the Peloponnisos, Greece. J. Herb. Med., 19, 100305 .

[28] Al-Fatimi, M. (2019). Ethnobotanical survey of medicinal plants in central Abyan governorate, Yemen. $J$. Ethnopharmacol. 241: 111973.

[29] Oladeji, O. S., Oluyori, A. P., Bankole, D. T. and Afolabi, Y. A. (2020) Natural Products as sources of Antimalaria Drugs: Ethnobotanical and Ethnopharmacological studies, Scientifica, $1-22$.

[30] Sonibare, M. A. and Ayoola, I. O. (2015). Medicinal plants used in the treatment of neurodegenerative disorders in some parts of Southwest Nigeria, African Journal of Pharmacy and Pharmacology, 9 (38): 956-965.

[31] Gbadamosi, I. T. (2019). Hidden Treasures of Ethnobotanical Medicine. A Faculty Lecture delivered at the Faculty of Science, University of Ibadan on $26^{\text {th }}$ June, 2019.

[32] Odoh, U. E., Uzor, P. F., Eze, C. L., Akunne, T. C., Onyegbulam, C. M. and Osadebe, P. O. (2018). Medicinal plants used by the people of Nsukka Local Government Area, South-eastern Nigeria for the treatment of malaria: An ethnobotanical survey, Journal of Ethnopharmacology, 218: $1-15$. 